\title{
THE
}

\section{The Epistemic Consumption Object and Postsocial Consumption: Expanding Consumer-Object Theory in Consumer Research}

\author{
Detlev Zwick \\ York University, dzwick@schulich.yorku.ca \\ Nikhilesh Dholakia \\ University of Rhode Island, nik@uri.edu
}

Follow this and additional works at: https://digitalcommons.uri.edu/cba_facpubs

Part of the Critical and Cultural Studies Commons, E-Commerce Commons, and the Marketing

Commons

Terms of Use

All rights reserved under copyright.

\section{Citation/Publisher Attribution}

Zwick, Detlev, and Nikhilesh Dholakia. "The Epistemic Consumption Object and Postsocial Consumption: Expanding Consumer-Object Theory in Consumer Research." Consumption, Markets \& Culture, Vol. 9, No. 1 (March 2006): 17-43.

DOI: $10.1080 / 10253860500481452$

This Article is brought to you for free and open access by the College of Business at DigitalCommons@URI. It has been accepted for inclusion in College of Business Faculty Publications by an authorized administrator of DigitalCommons@URI. For more information, please contact digitalcommons-group@uri.edu. 


\title{
THE EPISTEMIC CONSUMPTION OBJECT AND POSTSOCIAL CONSUMPTION: EXPANDING CONSUMER-OBJECT THEORY IN CONSUMER RESEARCH
}

\author{
Detlev Zwick, York University* \\ Nikhilesh Dholakia, University of Rhode Island** \\ *Detlev Zwick is Assistant Professor, Schulich School of Business, York University, Toronto, \\ Ontario. Phone: (1)416-736-2100 ext. 77199, Email: dzwick@schulich.yorku.ca. \\ ** Nikhilesh Dholakia is Professor of Marketing, University of Rhode Island, Rhode Island, \\ United States. Phone: (1) 401-874-4172. Email: nik@uri.edu
}

The authors thank the Marketing Science Institute and the Research Institute for Telecommunication and Information Marketing (RITIM) at the University of Rhode Island for funding for this research.

The authors thank Eileen Fischer, Robert Kozinets, and Markus Giesler for comments on earlier drafts of this paper. 


\begin{abstract}
We introduce the concept of the epistemic consumption object. Such consumption objects are characterized by two interrelated features. First, epistemic consumption objects reveal themselves progressively through interaction, observation, use, examination, and evaluation. Such layered revelation is accompanied by an increasing rather than a decline the object's complexity. Second, such objects demonstrate a propensity to change their "face-in-action" visà-vis consumers through the continuous addition or subtraction of properties. The epistemic consumption object is materially elusive and this lack of ontological stability turns the object into a continuous knowledge project for consumers. Via this ongoing cycle of revelation and discovery consumers become attached to the object in intimate and quasi-social ways. Therefore, the concept of the epistemic consumption object brings the "object" directly into theorizations of consumer-object relations, extending current theories of relationship, product involvement, and consumption communities. We draw from research with individual online investors to illustrate the theory of the epistemic consumption object.
\end{abstract}

Keywords: knowledge objects, postsocial, Internet, online trading, personal investing, consumerobject relationship, knowledge society, individualization, community, stock market 


\section{INTRODUCTION}

Consumer researchers have studied extensively the role of objects in consumer culture. Objects, widely defined as non-human entities, figure prominently in theories of the consumer self, consumer identities, and consumer communities (e.g., Belk, 1988; Holt, 1998; Kleine, Kleine, \& Allen, 1995; Kozinets, 2001; Mehta \& Belk, 1991; Penaloza, 1994). Sociological and anthropological studies have illuminated the often idiosyncratic rituals that consumers use to appropriate, decommodify, and singularize objects (e.g. Belk, Wallendorf, \& Sherry, 1989; for a review see Kleine \& Menzel Baker, 2004; Rook, 1985) and the many intricate processes that lead to psychological and emotional attachments to consumption objects (Belk, 1992a; Kleine \& Kernan, 1991). Furthermore, material objects take center stage in the construction of narratives of belonging, identity, and collective memory, particularly during moments of transition and transformation (e.g. Belk, 1992b; Bonsu \& Belk, 2003; Holt, 1995; Wallendorf \& Arnould, 1988)

Consumers become highly and enduringly involved with objects that arouse, interest, and stimulate them. They become avid collectors and members of object-centered consumption tribes (e.g. Baudrillard, 1994; Benjamin, 1968; Maffesoli, 1996; Schouten \& McAlexander, 1995; St. John, 2004). Sport fans often stay involved with particular teams for entire lifetimes (Giulianotti, 1996; Holt, 1995), exhibiting sometimes extreme forms of "passionate consumption" (Belk, Ger, \& Askegaard, 2003), while pet owners have been documented to have

elevated levels of pet-related deep involvement ${ }^{1}$ (Hirschman, 1994; Holbrook, Stephens, Day, Holbrook, \& Strazar, 2001).

In the final analysis, all consumer research about objects is about relationships. Marcoux's (2001) rich study of strategies of object (possession) divestment illustrates the 
multifaceted set of social relations that are negotiated through, constructed by, and folded into material objects. Cova (1997) and Kozinets (1999) argue that objects create and sustain relationships between individual and community, while social and cultural theorists have discussed the crucial role of objects, particularly commercial objects allocated by the market, in the (re)production of class, gender and racial relations (e.g. Bourdieu, 1984; Comaroff, 1996; Schroeder \& Zwick, 2004; Sparke, 1995).

In this paper, we introduce the concept of postsocial consumption to make sense of an emerging form of consumer-object relationship that is increasingly characteristic of technologyand knowledge-intensive societies (Stehr, 1994). Guided by social theory on individualization and sociality in late-capitalist knowledge societies (Beck \& Beck-Gernsheim, 1996; Beck \& Beck-Gernsheim, 2002; Knorr Cetina, 2001; Knorr Cetina \& Bruegger, 2002b; Stehr, 2001b) and data gleaned from long-term research involving individual online investors, we propose that consumer relations with objects become an end in itself. Put differently, in societies characterized by risk (see e.g. Beck, 1992) and knowledge (Stehr, 2001a), consumers turn to certain kinds of objects, what we call epistemic consumption objects, to forge (quasi)social relations. Such relations with objects represent postsocial relations since they imitate, if not substitute for, more traditional social relations. In this sense, postsocial consumer-object relations add an additional dimension to consumer-object relations that pursue utilitarian and second-order goals, such as contributing to self formation, identity construction, life project support, and meaning provision for individual consumers. The next section discusses individualization theory and the emergence of postsocial relations, knowledge society, and the epistemic consumption object. After explaining our methodology and research site, we judiciously draw from interview 
data to illustrate how postsocial consumer-object relations manifest and express themselves in a specific consumption context.

\section{Individualization and Consumption Communities}

Individualization of societies is not a new phenomenon. Classical sociologists from Durkheim and Marx to Weber and Simmel left us with instructive accounts of the abrasive effects of industrialization and modernization on traditional forms of interpersonal and community relations. The rise of cities, the dominance of industrial production, professional bureaucracies, and individual mobility - all these undermine traditional socialities based on spatial proximity, local cultures, or kinship relations (Bouchet 1998; Cohen, 1985; Tönnies, 1979). Religious worldviews, previously stable and stratified social hierarchies, and social institutions are all diminished as organizing principles (Giddens, 1991; Habermas, 1981; Weber, 1958). Rather, the nuclear family and the formation of a private sphere emerged as $20^{\text {th }}$ century responses to the breakdown of traditional communities (Wallulis, 1998). Yet, the project of reflexive modernization (Beck, Bonss, \& Lau, 2003) radicalizes modern societies further by disembedding the individual from even these "primordial social relations" (Knorr Cetina, 2001, p. 522).

The consequences of reflexive modernization are two-fold: the loss of conventional support systems and the emancipation from "natural" dependencies. In other words, the liberation of the subject is irreducibly connected to the requirement for individual self-reliance, self-provision, and autonomy. In concrete terms this means that with the end of predestined life projects and linear career planning (Wallulis, 1998), both the range of options open to the individual and the imperative to make life decisions grow. Which school to go to, what career to choose; with whom to enter into a relationship; if and when to get married and have children; 
whether to change the spouse, the job, or the place of living - these are no longer predetermined by one's milieu or membership to a social class (Habermas, 1994). In short, in individualized societies the individual must learn to regard himself or herself as the center of decision-making, as the "planning office" relative to his or her life trajectory, career options, and relationships.

The newly freed subject - in industry, in education, in management, in private life as consumer - is forced to take responsibility for every decision s/he makes. Long-term commitments are increasingly risky since they lead to inflexibility which may be detrimental for the future life chances of the individual (Sennett, 1998). The modern self's greatest fear is to mortgage her future, not keep her options open (Wallulis, 1998). Everything seems to conspire against lifelong projects and lasting commitments. Relationships are "until further notice" because they now depend on the satisfaction of the two partners (Bauman, 2003).

Over the past decade, there has been a significant rise in research exploring various forms and displays of common consumption interests (e.g., Belk \& Costa, 1998; Cova, 1997; Kozinets, 2001; McAlexander, Schouten, \& Koening, 2002; Muniz \& O'Guinn, 2001; Schouten \& McAlexander, 1995). Consumer researchers theorize that these consumption communities, (sub)cultures, and tribes represent a response to the erosion of traditional forms of sociality (Cova, 1997; Firat \& Dholakia 1997; Firat \& Venkatesh, 1995). Analogous to these arguments we suggest that postsocial consumption also arises from the conjunction of modernization and individualization. Yet, unlike researchers concerned with what Cova (1997) aptly calls the social linking value of objects (see also Marcoux, 2001; Miller, 1998), we argue that epistemic consumption objects increasingly supplement - and perhaps even in part substitute for - humans as relationship partners (cf. Turkle, 1995; Turkle, 2003) among consumers hoping to reverse the contemporary experience of individualization (Beck \& Beck-Gernsheim, 2002; Giddens, 1994). 
In other words, consumers experience a type of sociality with consumption objects that, while not completely replacing traditional forms of social relations and communities, increasingly competes with them.

To state the argument in a different way, we suggest in this paper that the current understanding of the "disembedding" of consumer selves in late capitalist consumer cultures underestimates the "re-embedding" force of consumption objects, not as social link and glue, but as social other. Hence, the postsocial model of sociality posits that a universe of increasingly knowledge-based and complex consumption objects challenge humans as the most desirable relationship partners. At a minimum, as Turkle's (1995) study of early netizens and their construction of a culture of simulation illustrates, "real" humans may no longer be what other humans pay most attention to.

Hence, our conceptualization of consumer-object relations goes beyond current theorizations of objects as material for consumer identity projects (e.g., Belk, 1988; Holt, 1998; Schau \& Gilly, 2003; Thompson \& Tambyah, 1999) and social glue for consumer communities (e.g., Kozinets, 2001; Muniz \& O'Guinn, 2001). Postsocial consumption is characterized by object-relations as a category of relationships that we theorize as increasingly competing with human relations (see also Knorr Cetina, 1997; Turkle, 2003).

\section{Postsocial Consumption and the Epistemic Consumption Object}

We adopt the concept of the "postsocial" from a body of sociological research that identifies and analyzes cultural forms of sociality that exceed traditional definitions of the social but which can be observed today in a increasing number of settings (Knorr Cetina, 1997, 2001; Knorr Cetina \& Bruegger, 2000; Latour, 1996). More of an analytical concept than a strict theoretical structure, postsocial relations refer to a world where individualization processes and 
the rise of consumer culture converge to precipitate a new form of sociality in which consumption objects of knowledge - what we have termed epistemic consumption objects - fill in for the human element. Prerequisite for the promotion of an object to a social 'other' is, however, its ontological 'opening up'; a procedure that has only recently begun to occur outside specific scientific and technological cultures (Knorr Cetina, 1999; Latour \& Woolgar, 1979).

We posit that epistemic consumption objects are characterized by two interrelated features. First, interaction, observation, use, examination, and evaluation of epistemic consumption objects "reveal them progressively", by increasing rather than reducing their complexity (Rheinberger, 1997). Second, such objects demonstrate a propensity to change their “face-in-action" vis-à-vis consumers through the continuous addition or subtraction of properties. In other words, the object is characterized by an essential elusiveness of look, content, shape, and "story." This material elusiveness or lack of ontological stability turns the object into a continuous knowledge project for consumers. While the epistemic consumption object is well defined in terms of its components and properties at any given moment, it is ill defined with respect to the direction it will take at the very next moment and in the less immediate future. A knowledge object may thus be called more or less ontologically liquid (or ontologically viscous) depending on the speed by which the object is revealed and the rate at which it changes.

This notion is not unrelated to Latour's concept of the "hybrid" or what Serres calls quasi-objects (Latour, 1993; Serres \& Latour, 1995). Such hybrid quasi-objects are neither purely natural facts (in a transcendental sense of being a thing-in-itself) nor completely socially constructed. Rather, these are actors in endless network of relations and that these networks of relations simply form more complicated actors, or hybrids. While Latour maintains that hybrids have always existed, he surmises that modern technologies, institutions, and laboratories tend to 
generate larger and more complicated hybrids than ever before. Hence, conceptually one could suggest, with Latour, that an epistemic object is one that has not yet entirely been purified (and ontologically sealed) by modernist discourses of science and culture. Such ontological openness enables an ongoing forming and mutating of relations around the object, thus adding to its increasing complexity as it is being revealed and discovered.

In can be stated, then, that the complexity of the epistemic consumption object is based on its material elusiveness - on the possibility of continuous revelation of its material components and their relations to each other. Such should not be confounded with a different kind of complexity relevant to consumer researchers: the complexity added to the object's meaning structure, cultural and social significance, and range of functionality by innovative and creative acts of consumption. As richly documented by cultural consumer researchers, consumers (re)construct seemingly mundane consumption objects as powerful and complex representations. In so doing, consumers often focus not on the products' encoded usages, but frequently displace products by putting them to unexpected use (Belk et al., 1989; Miller, 2001). According to this line of thought, a consumption object is complex because of its semiotic and functional elusiveness. Postsocial consumption - entailing the formation of quasi-social relations between consumer and the consumption object - is a function of what we call epistemic complexity, which refers to the object's material elusiveness.

Material elusiveness points us to the fact that epistemic consumption objects are morphing and changing on the ontological level, and not just the semiotic and functional levels; and that this uncertainty about "what the object might become" motivates the consumer to persistently engage with the object. Similar to the experimental structure found in the scientific laboratory, it is this ongoing cycle of revelation and discovery, of defining and continually 
redefining the object as it acquires new properties and changes or sheds old ones, that differentiates an epistemic thing from an instrument or tool-like object. The central characteristic of epistemic objects, from a theoretical point of view, "is their changing, unfolding character - in the present terminology, their lack of 'object-ivity' and completeness of being, and their nonidentity with themselves" (Knorr Cetina, 2001, p. 528). As a result, the future of the object's face-in-action appears unclear and ill-defined; full of surprises, dangers, and promises; and these are precisely the properties that encourage consumers to get enduringly attached to epistemic consumption objects. Therefore, the epistemic consumption object represents the fundamental building block of postsocial consumption.

The rise of epistemic consumption objects is the result of a culture of science, technology, and consumption that has generated an explosion in the volume of non-human things with high "knowledge content" (Latour, 1987; Stehr, 1994). Technological and virtual objects, scientific objects, and also some non-technological consumer products fall into this category. Knowledge economy, knowledge society, networked economy, post-capitalist society, and information society are terms often used to capture this state of affairs (e.g., Castells, 1996; Drucker, 1993; Shapiro \& Varian, 1999; Stehr, 1994, 2001b). In a knowledge economy, increasing numbers of objects are knowledge-based, a characteristic that accounts for their changeability and sophistication (Drucker, 1993; Stehr, 2001a, 2001b).

Postsocial consumption is motivated by continuously anticipating, searching for, and relating to the next version that the object hides within itself; and the object never stops signaling its unfolding possibilities. Thus, this time the river carries more water, is faster, and requires a different approach to rafting; the skydive in the mountains offers new vistas but also new dangers; the next generation in artificial reproduction technology has the fix for childless 
couples; the next The Sims extension pack delivers new environments and lifestyles; etc. On a theoretical plane, we can say that the object has been opened up ontologically and become a thing that is always already in the process of transformation.

As the role of knowledge becomes dominant in the constitution of consumption objects, changing them from stable and definite commodities to evolving, materially indefinite, and question-raising objects - consumers reconfigure their rapport with these objects. In this sense, both sides - the consumer and the object - feed and sustain each other. In so doing, they fulfill one condition of a relationship, "which is that it should continue over time and not be reducible to an action or a short experience" (Knorr Cetina \& Bruegger, 2002b, p. 178). Within postsocial relationships, the extension of the self is more accurately understood as an extension of relationships to the object world.

Examples of such cultural forms in consumer research have been described in the analysis of high-risk leisure consumption like skydiving (Celsi, Rose, \& Leigh, 1993) and whitewater rafting (Arnould \& Price, 1993) in relation to natural environments (see also Lyng, 1990), in the presentation of self in virtual environments (Schau \& Gilly, 2003), fans of a baseball club (Holt, 1995), the configuration of Star Trek as relationship object (Kozinets, 2001), and the kind of attachments described in this paper. In what follows, we use "the stock-marketon-the-screen" (Zwick \& Dholakia 2006) to illustrate the ideas about the epistemic consumption object, postsocial consumer-object relations, and the formation and expression of postsocial consumption.

Some might question whether the stock market should be regarded as an object at all. Alternative descriptions are well known. Economists see the market as made up of rational actions of free individual actors and economic sociologists consider the market to be a network 
of institutions structurally linked by processes of production, consumption, and distribution (e.g., Swedberg, 1994). Consumer researchers typically disassemble the market into its human components by analyzing the interactions, experiences, and exchanges between consumers and marketers (e.g., Penaloza, 2001). For the purpose of this paper, we are interested in the market as an on-screen object - perceived by the individual online investors sitting in front of their computers, researching stocks, and making deals. The ongoing unfolding of new communication and information technologies on the field of global financial flows allows for the exteriorization and visualization of the market on the computer screen. Thus rendered, the market can be seen as an object of observation, interaction, and, hence, consumption - no too different from other onscreen epistemic objects like multi-person games. In addition, 'finding the market', which in the past imposed a significant barrier of entry for masses of small investors, is no longer a problem. The Internet and the computer have turned the stock market into a wide-open online shopping mall for stocks.

THE STUDY

\section{The Individual Online Investor}

The informants for this study are united in their excitement for 'the stock market.' The Internet makes it very easy for them to participate in 'the game' of global finance and they look forward to the time of the day when they can strap themselves to their chairs in front of the computer and 'play.' As some of the informants describe it, they are 'glued to the screen', cognitively immersed in the action and physically tense, often nervous. As the computer captures the unpredictable and chaotic high-technology vortex of informational turbulence that characterizes the trading floors of stock exchanges in New York, Tokyo, and Frankfurt (Abolafia, 1996; Castells, 2001), investors come very close to a phenomenological sense of 
being-in-the-market (cf. Sherry, 1990). The experience echoes the science fiction account of individuals 'jacking themselves into' cyberspace in William Gibson's Neuromancer, the novel to which we owe the term 'cyberspace'.

The German and American online investors interviewed for this study consider themselves to be part of the technological and cultural avant-garde. Particularly in Germany, where investing in the stock market has long been regarded as a somewhat suspicious activity of praetorian financial institutions and a few wealthy, sycophantic individuals, online investing was from the beginning endowed with the air of the exotic, exciting, and even dangerous (Burns, 1995; Staute, 1998). Some informants liken it to entering the Byzantine worlds of console video games [e.g., Doom, Half Life, Stalker], where death and disaster seem imminent and each new advance increases the threat level. In addition, our informants often seemed fatalistic about the stock market, stating that it will come to play an ever increasing role in our lives, "whether we like it or not", and that it is preferable to play an active part in it than merely be a passive observer of it.

The computer reconfigures the market as a specifiable space to which individual online investors are attached. Online brokers play an important role in supplying a recognizable surface, or a face-in-action (Knorr Cetina \& Bruegger, 2000), for the market. Correspondingly, even during the interviews the gaze of our informants is focused on the screen. They read incoming emails with titles such as 'investor alerts' and 'breaking news', skim the inevitable and infinite ticker stream, keep an eye on their portfolios and research interesting new finds. In addition to the broker's site, informants often have additional windows open to survey political, economic, and firm-specific information and to meet and communicate with other like-minded investors in various chat rooms. Finally, some informants even conduct trades during the interview, 
sometimes to demonstrate the mechanics of trading, sometimes because of an opportunity that presents itself (auspicious development signaled by the chart of a particular stock, a tip from a chat room buddy, suggestion by "investment zine" such as Motley Fool, etc.) - that requires immediate action.

Our informants come from middle class backgrounds, even though some do not have regular jobs and income (Bourdieu, 1984). Financial contributions in absolute terms differs across the informants but their cognitive involvement is generally high, as evidenced by the enthusiasm expressed for the subject of online trading during interviews. Our informants are united in their desire to 'make money.' Yet, fulfilling the desire entails developing an intimate relationship with the market, which was much more than most had bargained for when they took up online investing.

\section{Data Collection}

The study is based on an analysis of textual data from verbatim transcripts of long, indepth interviews (Thompson, Locander, \& Pollio, 1989) as well as data gathered during followup email exchanges with some of the informants. Participants were recruited through personal contacts and referrals. At the time of the interviews in 2000, informants had typically between 18 to 24 months of online investing experience. Only two informants had done some trading of stocks and currencies prior to taking up online investing. All other informants were first-time and do-it-yourself investors who used the Internet to enter the investment game, disintermediating banks and other financial institutions. All but four interviews were conducted at the informants' workplaces or residences and lasted between 60 and 120 minutes. Typically, interviews took place in front of the computer, often while logged on to the informants' online trading accounts. 
Twenty-five participants, 14 Germans and 11 Americans, were interviewed. Table 1 shows the profiles of the participants. They can be characterized as technology-savvy, selftaught, and frequent traders. For the purpose of this study (and consistent with the criterion used by online brokerages) we define everyone who conducted at least one transaction per month as a frequent trader. Typical transactions consisted of the purchase or sale of a few shares ranging in total value from less than one hundred to several thousand dollars per deal. Absolute and relative amounts invested differed significantly from informant to informant. In general, however, individuals with low levels of total wealth and income were more likely to have a high percentage of their available funds invested in stocks. At the time of the interviews, Christian, a student, and Oliver, a teacher-in-training - both with little savings and low monthly income had anywhere from eighty to one hundred percent of their wealth locked up in the stock market. By contrast, the portfolio of Theo, a well off attorney, represented less than $20 \%$ of his overall financial assets.

Follow-up interviews were conducted with eight informants for the purpose of clarification, elaboration, and revision of key issues. Four informants, including the case presented below, remained active participants for about twenty-four months after the initial interviews as part of an ongoing unstructured email correspondence. ${ }^{2}$ All informants were assured of their anonymity and given the opportunity to read the transcripts of their interviews and to remove or disguise any information that might reveal their identities.

Insert table one here -

CONCEPTUALIZING POSTSOCIAL CONSUMPTION 
The Market as Epistemic Consumption Object

Our concept of postsocial consumption hinges on the notion of the epistemic consumption object. Therefore, we first address the question of the nature of the epistemic consumption object by using "the stock-market-on-the-screen" as our exemplar consumption object. When an individual online investor sits down in front of her computer screen to check up on the market, to assess the content and valuation of her portfolio, and to zoom in on a transaction, she does tremendous hermeneutic work integrating fragmented and diverse streams of information pouring in from many different sources. To manage the flood of information, the investor often operates several layers of windows simultaneously, covering the status of stock markets around the world - headline news, analyst commentaries, and conversations taking place in various chat rooms. Typically, the individual online investor only has a limited time available during the day to spend on the market. Therefore, they typically start their online investment time by "catching-up" with recent developments and current events in order to discern the market's current 'story.'

So these days I'm on my computer from anywhere from 8 or 8:30 AM to 4-4:30 PM. I don't look that much outside of those times. But inside these times, I am engaged with the market. I'm literally glued to the desk. [...] It's obviously during work time so I have to go back and forth, read up on things I might have missed while I was in a meeting. The goal is to stay on top of this thing, make sure to be ready when it moves one way or another. The market is really volatile these days so there is a lot to cover, you know. At a minimum, I check the ticker here at the screen but whenever there is an opening here at work, I'm on Yahoo! Finance or CNBC.com [now part of MSN moneycentral]. (Eric, 43, ad designer, American) 
But picking the top is the hard part to do. You gotta really know. Some people do, but then it really depends on what sector you are in. Like right now you can get into tobacco, some safe sector, some defensive position and you have to educate yourself and I have read some books along the way, of course, on how to invest. So I wasn't going to make some stupid business decisions. Investors' Business Dailies was that newspaper I was reading daily. Just trying to stay put for awhile and go with the safe havens like tobacco and oil of course and trying to avoid the dangerous ones. Get back on the fast track when the market changes. You gotta be ready for that though because when that happens you want to be there. Right now, I am careful. Oil is doing pretty well because of the supplyand-demand issues, see here [pointing at screen]. (Kenny, 42, professor, American)

So, I sit there and watch it and OK, this is, it's kind of interesting to watch. And I sit there I'd be like, OK, what is gonna happen next? You know, what are they [the other chat room members] gonna say? It's kind of like a soap opera. What's the company gonna do and what are they gonna say? Like when does their forecast come out, when does their earnings statement come out? And then what are the investors gonna do? It's like, alright, now would be a good time to buy. Or now would be good time to sell. I keep thinking what would be a good time or what should I do in this situation. So that's why I wanted to research the short selling situation, learning by doing it, when is a good time and apply it in real world? (Keith, 22, student, American)

The need of our informants to observe, collect information, interpret, and be ready to act at all times corresponds to the unfolding nature of the market. They use the windows to 
aggregate the market's action, locate its perils and opportunities, deduce its story, and give the market a "gestural face" (Knorr Cetina, 1997; Knorr Cetina \& Bruegger, 2002b). These are the routines that constitute the market-as-knowledge construct for those who want to participate in it. The segmented pieces of information that traders assemble, however, arrange the stock market as knowledge construct but not yet as an epistemic consumption object in the sense developed in this paper. In their definition of the epistemic object, Knorr Cetina and Bruegger draw on the work of Rheinberger $(1992 ; 1997)$, who applies the concept to the scientific or research object that is at the center of processes aiming at materially defining this object. For example, the physical, biological, and chemical sciences continuously produce and discover new objects. Yet, at the moment of their creation and discovery these objects are still very much undefined, and explanations of what they are often rely on simply citing the elements and processes that went into conceiving them (see also Latour, 1987). The scientific process that ensues continually redefines the object ontologically by adding or taking away certain items used for describing and constituting the object. Therefore, epistemic objects always "present themselves in a characteristic, irreducible vagueness. This vagueness is inevitable because, paradoxically, epistemic things embody what one does not yet know" (Rheinberger, 1997, p. 28). Hence, epistemic objects in the context of science and research are not simply defined by their knowledge content but by the possibility to learn more about them. The epistemic thing signals to the scientist that there are new things to discover, new questions to answer, and many more doors to open in what seems like a continually expanding hallway.

Hence, in our interpretation, an object is constituted as an epistemic consumption object when it contains the capacity to unfold, evolve, change, and morph indefinitely, generating questions that consumers are willing to answer. Knowledge content is critical for the object 
because knowledge embodies the possibility for its continuous ontological opening up. Consider the stock-market-on-the-screen, which appears as an incomplete and nebulous structure that keeps eluding investors' attempts to get a "fix" on it despite the profusion of information available.

Do you think you can predict the market?

Of course not! No one can do that except perhaps for the professional investors that can spend all day watching the market. I don't know, though, if they really know what they are doing either. Most of them can't even beat the DAX [German equivalent of the Dow Jones Industrial Average] with their mutual funds. I may be able to predict to a certain degree where individual stocks might be headed. At least I would hope so. I do a lot of research and pay attention to what goes on with the few companies I own shares of, and then I listen to what others say and what the market as a whole does. So at the end I hope that when I make a decision it's based on a sound understanding of all the facts. The reality is that the next day when you look up the stock price and it's down, you have no idea why and what just might have happened. So you start the process of checking out the news, read the reports, basically make some sense of the whole thing. But that much I have learned over the past two years. Making sense of the market is very challenging because it changes all the time and there is always more information you have to pay attention to. (Joachim, 36, teacher, German)

Not even [Federal Reserve Board Chairman] Greenspan [knows how the economy will turn out to be in a few months from now]? 
Certainly not him [grins]! Seriously, there are so many factors that influence the market. No one has any clue what will happen next week or in a month from now, let alone in a year or two. You can research and watch as much as you want, it's absurd to claim you know what the market will do next and I don't care who they have on [financial TV show, with impresario] Louis Rukeyser. The moment you believe you have the market figured out and you can sit back and enjoy your ride, you better get out. This thing is going to make you pay if you let down your guard even for a moment. Especially in the current climate. This market is so volatile, it's crazy! Basically you are just reacting to how the market moves every day. Maybe look at some big players and do what they do, where they move their money. Be ready when the market moves up or down. It's totally stressing me out but it gives me a kick throughout the day as well. (Eric, 43, ad designer, American)

The comments of our informants portray a phenomenological disposition that is amenable to characterizations of the market-on-the-screen as independent 'life form'. Individual online investors refer to the market repeatedly as a "thing" that keeps changing in "front of your eyes" and "tells you what to do". Discerned as an unfolding and morphing structure that reveals and conceals its identity at every step while simultaneously providing and withdrawing cues for investors, the anthropomorphic market appears to have a mind of its own (cf. Knorr Cetina \& Bruegger, 2002a; Knorr Cetina \& Bruegger, 2002b). Investors attempt to position themselves "inside the market" and discover where this "life form" is moving and what it is "up to" next. This characterization as "life form" is also what points us toward the possibility of the epistemic thing as relational object. Perhaps it is no surprise that it was the biotechnologist Rudolf who puts it most distinctly. 
You have got to get inside the belly of the beast, really penetrate the market and work it from the inside. That's what I have learned so far. On NTV [German equivalent to CNBC or CNNfn] you don't find what you have to look for. The market is too smart for TV is what I always say. You get a simple story but then there is the real story behind that one. So, the Internet is better to get a feel for what the market is up to and what is going to happen next. I believe that the market has ways to let you know its next move but it doesn't make it easy. It's like the market designed this treasure hunt for us and now it's up to us to figure out how to pass all these challenges like Indiana Jones, you know. It gives you hints but also tries to mislead you with false traces so you really have to pay attention to the signals if you want to get the reward.

How do you know you can trust what the market is saying? What hints to go for?

Well, it's sometimes the repetition of things, when they are repeated over and over again you feel like the market is trying to tell you something here. You may see an upgrading of the stock by the banks and you remember that a few days ago in the chat room here [points at computer screen] some guy mentioned it and finally the chart looks good, well, you feel like this time the market is for once pretty loud and clear about what it wants you to do here with that one. (Rudolf, 36, biotechnologist, German)

The market is conceived by Rudolf as a scheming and cunning entity that will not give away its riches easily. To know what is on "its mind" (Smith, 1981), investors need to get "intimate" with the market, see through the ruses and maneuvers it uses to mislead, and face up to the challenges it poses. The market present itself simultaneously as an alarming opponent and a munificent partner in a never-ending game of treasure hunt, in which the market is defined as much by the things it conceals as by the things it reveals. As we noted earlier, the market's ever- 
changing and unfolding character is at the center of its ontology and this "lack of completeness of being" (Knorr Cetina, 1997, p. 170) is precisely what spawns and sustains the trader's interest in the object.

So you never invested in the market before [the advent of online investing]?

No. For me, investing became interesting once I could do it myself with my computer. The Internet changed everything. The financial world did not mean very much to me before. I would have never picked up the newspaper and read up on share values in the business section. Just pick up the Wall Street Journal and look at the pages where they list all the stocks and stuff. Puts you right to sleep. With the Internet the whole thing comes to life. It's in real-time, you can see the market change right in front of your eyes and I am waiting for the right moment to sell or buy. The market never stands still and something is always happening, so somewhere buried in all the numbers and analysts' reports you can find opportunities to make money. Often I look at my stocks and I'm thinking “c'mon, climb just 50 more cents and I'll sell that thing" and sometimes it happens and sometimes it doesn't. (Keith, 22, student, American)

I remember I was on vacation, it was spring break and I was somewhere in New Hampshire and then the market just dropped. Look at that drop there [pointing at a historical chart on computer screen]. I had sell programs in place like when a stock went below thirty like Westel, it was at forty dollars and I had a sell stop in at thirty-three dollars, I believe is what I had it at and it blew right through my stocks. All my stocks, it just blew right through these sell stops and I thought, wow! I mean, this market changes 
on a dime. Wanna get a hold of it? Good luck, right? You think you have seen it and tomorrow it is a whole different ballgame again. (Kenny, 42, professor, American)

Some days the market goes nuts, Wall Street goes nuts. You sit in front of the computer and you can't believe the speed at which things move. Like, my portfolio can change by twenty per cent in one hour. I've seen it happen. It's after such days that you go home and you are really thinking "shit, what's gonna happen tomorrow? Should I sell that stock or hold it a little longer? Maybe I should have sold it when things picked up. ” And all kinds of things go through your mind. Then you have a meeting in the morning, so you are stressed out about that. Anything can happen in three hours. For all I know, in this market, I come back to my desk and my money just went up in smoke. You need nerves, for sure. (Eric, 43, ad designer, American)

Individual online investors are enthralled by the market-on-the-screen not because of what it is at any particular point in time but what it might become. As Knorr Cetina and Bruegger (1997, p. 170) put it, "markets have their moments of fixedness when prices 'lock', but behind such fixed facades they always prepare to mutate, and at times explode, into something else." In other words, the epistemic consumption object is desirable not because it maintains a stable state of being, an absolute identity with itself that consumers can easily grasp and consume. On the contrary, consumer desire is generated by the object's mutability and complete lack of ontological stability, which fuels the consumer subject's continuous wish to explore and discover (see also Belk et al., 2003). From a semiotic perspective, a key characteristic of the epistemic consumption object is its ability to display to the consumer areas for further inquiry that sparks a sequence of exploration, discovery, and more exploration. 


\section{How long have you been investing online?}

For about three years now.

And you are still having fun with it?

Yeah, it's great. I love it. I've lost a lot of money by now but I told my wife the other day, I said, it's like paying tuition. You learn something even when you lose money, right? I started out in technology stocks but have gotten into biotech when that started moving, and now I've gotten out again then I tried some futures to see how that works and I got really burned there. But I learned something new, right? I'll probably try it again some time. $[\ldots]$ The thing with the stock market is that it's opened up a fascinating world for me that just keeps surprising me. And the more I learn about investing, or at least the more I think I know about stocks, ratios, charts, and projections, the more the market comes to life for me (Kenny, 42, professor, American)

The market is magic, to use one of Sherry's (1990) suggestive terms, because it comes to life and keeps evolving, shifting, and moving; offering possibilities for extending the complex game of investing in other corners of the market and with new strategies. Unforeseen events occur all the time, transforming the face of the market in a blink of an eye and signaling opportunities for new discoveries. Undoubtedly, relative to knowledge objects found on the workbenches of scientists or the shelves of supermarkets, the market-on-screen may be considered an accelerated epistemic consumption object because of the speed with which it changes and the fact that it "never sleeps." To reiterate, a consumption object is an epistemic consumption object not simply by virtue of its knowledge content but because of its unfolding and morphing nature, its material elusiveness and lack of ontological stability. The consumer's motivation to turn the consumption object into an ongoing knowledge project is fueled by an 
awareness that the current set of properties making up the object is merely a transitory state of affairs and that an unknown and unpredictable future lays ahead.

The ontological openness of the epistemic consumption object is at least partly the result of the knowledge work of the consumer. As Kenny's comment reveals, the more he learns about the market the more it surprises him. The more Kenny tries to 'pin down' the market with his reliance on knowledge markers, the less ontologically stable it becomes. The market comes to life for Kenny because learning about the object means to recognize its complex past, precarious present, and indeterminate future. In theoretical terms, by adding to the object's knowledge content his own changing knowledge, Kenny amplifies the object's ontological liquidity. Having introduced and discussed the concept of the epistemic consumption object, we now explore its implications for relationship, involvement, and consumption community theory.

\section{THEORETICAL EXTENSIONS FOR CONSUMER RESEARCH: RELATIONSHIP,} INVOLVEMENT, COMMUNITY

The epistemic consumption object, defined as an ontologically open, unfolding structure that is non-identical with itself (Knorr Cetina \& Bruegger, 2000) is useful for extending current relationship theories (e.g., Fournier, 1998), theories of product involvement (e.g., Coulter, Price, \& Feick, 2003), and theories of consumption communities (see Cova, 1997; Kozinets, 2002a; McAlexander et al., 2002; Muniz \& O'Guinn, 2001).

\section{Relationship with Epistemic Consumption Objects}

The emergence of the epistemic consumption object opens up new avenues for theorizing consumer-object relationships. Current conceptualizations of relationships in marketing and consumer research have been consumer-centric. Fournier's (1998) work on consumer-brand 
relations presents a good example of such an approach. Her interpretations are guided by an action-oriented framework in which consumer relations with brands are motivated by instrumental reason and practical action (see Holbrook et al., 2001). In other words, consumers relate to brands because brands fulfill some utilitarian function in the consumer's myriad projects of self-enhancement, community formation, and identity construction.

Our object-centered approach does not reject or negate consumer-centric interpretations that see brands and consumption objects as instruments for practical action. For example, consuming the "market-on-the-screen" could fruitfully be analyzed from an action-oriented perspective exemplifying the role of stocks for the formation of consumption socialities (e.g. virtual investment communities) (see e.g. Bagozzi \& Dholakia, 2002; Kozinets, 2002b), and the extension of self into global flows of money and information (Appadurai, 1993; Castells, 1996). Yet, even as consumer-centric conceptualizations remain important in deepening our understanding of the importance of market- and marketer-supplied cultural material for contemporary consumers, they are no longer sufficient to grasp the nature of consumerobject/brand relationships that are rooted in the ontological qualities of the knowledge-based, ever-morphing epistemic consumption objects. Hence, postsocial object-relations theory, centered on the epistemic consumption object, complements traditional relationship theory by offering an interpretation of consumer-object relationship that puts the focus on the ontological qualities of the object as instrumental in the mechanism of binding consumer self and object.

Our extension to existing consumer-object relationship theory is premised on the assumption that consumers relate to objects "not only as 'doers' and 'accomplishers' of things within an agency framework but as experiencing, feeling, reflexive, and remembering beings as bearers of the sort of experiences we tend to reserve for the sphere of "intersubjective 
relationships" (Knorr Cetina, 1997, p. 163). Of course, we do not suggest that postsocial object relations are just like social relations between humans. Unlike research on brand relationships and product involvement, we do not focus on the relationship between objects and consumers as constituted and expressed by deep emotional connections and fulfillment, although we recognize that such relations exist (Moon, 2004; Turkle, 2003). We are more concerned about the mechanism that binds the consumer with the object in a mutually reinforcing and enduring sociality. Hence, we theorize consumers' relationship with the market-on-the-screen as constituted by a back-and-forth between the object, which continuously morphs into something new; and the consumer, who continuously anticipates and chases the always absent object.

I'm addicted to the stock market. You know, we had $\$ 3000$ in our savings account and it was just sitting there and nothing was happening with it. You put it into the stock market and it's like getting on a roller coaster, right? Your portfolio keeps changing every night, the market is fickle and, you know, basically unpredictable, you checked on your stocks in the morning and they looked good and then at night and all your gains might be gone. They have this list of stocks on CNBC, the 'Big Movers' of the day. And you want to have the Big Mover. I've been looking for the next Microsoft or Dell and there will be another one. That's how the market works. It produces wealth and I want to be in the right place at the right time when it washes up another gem. Compare that to my savings or checking account where nothing ever happens, you know. For me, moving my money into the stock market changed my life. (Kenny, 42, professor, American)

I have made this my routine. I have breakfast in front of my computer to check what the market looks like, what the breaking news are, how my portfolio is doing, and if there 
might be anything happening that day that could affect it. My wife is already getting annoyed by my interest in the market. Anyway, then during work I usually check in and then at night, I spend at least an hour online reading market news and making trades.

\section{And you are not getting bored?}

It's not boring at all. There is always an opportunity to make some money or well, these days it's rather a danger to lose money. There is always something going on, new stuff happening, political events, war, you name it. The market is always affected by everything and therefore anything can happen and it's not enough to just look at numbers or charts, although that's important, too. As long as you have money in there, the game keeps going on. That's what it is for me: it's a game, but a serious game. (Eberhard, 37, journalist, German)

In a follow-up interview with Eberhard about twelve months later, he returned to game metaphor.

It's exactly what I was thinking the other day when I set up my son's computer. He turned eight years old and he wanted a computer so he can play games like his friends. We said fine and bought it. When I loaded the games and we looked at them I said to my wife that this feels just like my online trading. I realized that to a certain degree online investing is a video game for grown-ups. The Internet made the stock market and investing a mature computer game. It never ends; well hopefully! It has an unpredictable plot with new tasks and evil enemies just around the corner waiting to take your money from you, and it's about significant amounts of money! (Eberhard, 37, journalist, German) 
Informants frequently made the connection between investing and playing a game and the role that the Internet and the computer screen have in simulating a gaming and entertainment environment. Observations during interviews substantiate claims of intense involvement with the market and the fun and excitement investors get out of interacting with all the things that constitute the market in their minds. They were eager to show off their knowledge and skill in maneuvering the stock market and interpreting signs and signals pouring in from all corners of the screen. From a theoretical perspective, it was the never ending sequence of challenges presented by the market and consumer's continuous desire to meet them that translates into a type of relationship where both sides feed off of each other. Most signals that motivate consumers to continue their involvement emanate directly from the market but investing friends and colleagues also become further impetus for engagement.

Of course I always talk to friends and colleagues of whom I know that they do online trading as well. There are few I trust and we always talk about tips and [industry] sectors that might become hot for one reason or another. I have a friend who works as a biochemist at a bigger company here in Munich and we talk about the biotech sector and what companies might be interesting because of the research they are doing and the products they are working on. It's a good sector for us because we know it and because it's happening, especially right now. We have been waiting on a few stocks to really break out and I think it's going to happen now soon as some companies are in the final stages of their [new product] trials. (Rudolf, 36, biotechnologist, German)

Whether the signals of what the market might become emanate from the market itself or from other sources including friends is less important for maintaining the relationship than the fact that these signals continue to be sent and interpreted. This mechanism ensures that the 
contemplated and desired consumption object can never be fully attained because it exists only as a sequence of absences. This is the crux of the postsocial relationship between the self and the knowledge object. The self is motivated to continuously anticipate, search for, and relate to the next version that the object hides within itself. The object never stops signaling its unfolding possibilities (the Big Mover, the breakout stock, the next crash). In this sense, the investor and the market are intertwined in an ongoing and mutually sustaining bond.

\section{Involvement with Epistemic Consumption Objects}

Consumer research defines involvement as an expression of extrinsic and intrinsic motivation. Extrinsic motivation applies to activities performed because they are instrumental to achieving a valued outcome and intrinsic motivation applies to activities performed as ends in themselves ( see also Davis, Bagozzi, \& Warshaw, 1992; Hoffman \& Novak, 1996, p. 61). Involvement endures when somehow the product or the product category continuously relates to consumers' values, goals, life projects, and concept of self (Bloch \& Richins, 1983; Coulter et al., 2003; Zaichkowsky, 1985). We also know that involvement focuses attention toward product and marketing messages (Celsi \& Olson, 1988; Zaichkowsky, 1986).

Until Coulter et al's study (2003), very little was known about the origin of product involvement. Coulter et al. (2003) argue that object involvement is activated when consumer's life themes and significant macroenvironmental, sociopolitical, and cultural influences intersect onto particular products and brands (for a similar view see Fournier, 1998). The Coulter et al. study, however, is vague when addressing the question of sustained involvement, theorizing that involvement endures as long as the life-project/macroenvironment dialectic endures. We suggest that involvement with epistemic objects is fueled by the nature of the object of involvement (which involvement researchers, including Coulter et al., treat as a black box). 
Making money is still part of the fun, although it has been less fun lately. For sure, money is part of it. So, for say retirement planning and such things I put money in mutual funds for security reasons. The real fun, what really keeps me going, is the action you get when doing it to yourself. When your money is in a mutual fund you don't get that feeling at all. It really blew me away at the beginning when I just started out that when I did my first trades I realized I was part of the stock market. There was this thing in front of my eyes and it was definitely intimidating and mysterious but also fascinating and full of promise. Back then I had to check on my portfolio and my watch list [of stocks] every five minutes. I've calmed down for sure but three to four times a day I check up on things, no doubt. (Peter, 36, professor, German)

External forces such as an insecure retirement system and instrumental motivation to make money and secure financial stability play a crucial role in prompting individuals to become involved with online investing. The newly available technological infrastructure also helps veer people toward do-it-yourself investing. Yet, once individual online investors have been exposed to the market on screen, the nature of the market becomes part of what sustains the desire to stay in it. Hence, it is no longer sufficient to understand involvement as a cognitive and behavioral response formed by environmental forces and intrinsic self-relevance (Celsi \& Olson, 1988). The degree of involvement exhibited by individual online investors toward the market on screen is as much a function of the nature of the object as of instrumental and autotelic motivations. If we insert historical analysis into our argument, we believe that the role of the object in the generation and sustenance of involvement will increase in the future because of increase in number, relevance, and use of epistemic consumption objects. Understanding the role of the 
object's morphing and liquid ontological qualities in activating and sustaining consumer involvement with the object should be put on the top of consumer researchers' research agenda.

\section{Consumption Community and Epistemic Consumption Objects}

Finally, we discuss the implications of our research for the vibrant debate on consumption communities. Researchers of Star Trek aficionados, baseball fans, Bronco lovers, and Harley-Davidson owners have theorized these consumers and their experiences as defining expressions of late (or a second) modernity, characterized by radical individualization and erosion of traditional socialites (Cova, 1997; Kozinets, 2002a). In other words, as detraditionalization (Bauman, 2003; Heelas, Lash, \& Morris, 1996) dismantles large social institutions and devalues long-standing symbols of collective identification, new forms of social organization emerge that are often grounded in common lifestyle interests and realized through consumer choice (Bouchet, 1998). Within this theoretical framework, consumption practices are comprehended as a social antidote to hyperindividualism by holding consumers together in more or less loose and transient tribal organizations (Firat \& Dholakia 1997; Maffesoli, 1996; Muniz \& O'Guinn, 2001). Some commentators even suggest that communities formed around brands and products exhibit traits of faith and solidarity reminiscent of religious groups (e.g. Belk \& Tumbat 2005; Cova, 1997; Kozinets, 2001).

There remains little doubt, then, that at the beginning of the $21^{\text {st }}$ century, individuals increasingly "turn towards objects and services" to find a "social link" (Cova, 1997) in a world that lacks traditional collectivities and non-commercial networks of solidarity. Yet, despite its explanatory power, this social-link approach of theorizing the object as a catalyst for consumer community and intersubjectivity ignores the degree to which the modern untying of socialities has been accompanied by an expansion and increased relevance of object-centered environments 
(Knorr Cetina, 2001). In particular the ontological quality of the objects to which consumers relate such as information and communication technologies, cultural objects, nature, the market, and brands (Fournier, 1998) - indicates that a shift toward object-centered socialities might emerge as an additional social structure and a real alternative to consumption communities.

In other words, consumers commune and socialize with the object of consumption, generating a formula of "mutual providing" (Knorr Cetina 1997) that becomes the backbone of reciprocity for the object-centered sociality. Crucial for this object-centered solidarity to occur is the consumer recognition of the object of consumption as an object of knowledge. Only if the consumer has intimate knowledge of the object, indeed comprehends it as an epistemic consumption object, can she decipher the signs given off by it to determine what it is still lacking.

I think one reason why I have such a hard time deciding on a particular trade now, which I never used to before, is because I know the market better than before. I know that there are more things to take into consideration than just the chart. I always tell my wife online investing is like learning French. The more you learn the more you realize that you really don't know much about French yet at all. It takes more nerve now than when I just started out because I had no idea back then what mattered and what didn't and so after I made some money I really thought I had this thing figured out. It's not that hard, I thought. Much has changed since. I have lost a bunch of money and I have learned that making money in the market is hard work. If I want to beat the market, as they say, do your research and put in the time it takes to figure out the company, the industry, everything. So, some day you will be able to know for sure whether this stock or that will make money? 
Ideally yes. But I really don't think I will ever get there. You learn and research and you look at all kinds of indicators and ratios to evaluate a company, you read all analyst reports on that company, and you feel pretty good about your decision and the next thing you know is that the stock is a big loser and then you learn what you should have looked at was something totally different. I lost about 2000 euros in three weeks on a stock for that all indications were good. The stock seemed undervalued, the pipeline looked strong, the chart was screaming 'turn-around' and after I bought it went up from something like 7 euros to almost 10 and then, whooooom, down to 3 in a couple of days. What happened? Well, there was a problem with an accounting probe which was under way even before I bought the stock and I knew about it but did not really count it in. (Rudolf, 36, biotechnologist, German)

The consumer self is entangled in a continuing activity of learning about the object, while the morphing and always incomplete object continuously signals ever more possibilities for learning. Through this process, the object becomes instrumental in constituting the consumer self as a desiring actor, while the object, the market, becomes defined and articulated through the investor's acceptance to explore the market's mysteries and ambiguities, to test and try it, to face up to it, and to answer the questions posed by it. Hence, sociality with objects such as the stockmarket-on-the-screen is the result of "a match between a sequence of wantings and an unfolding object that provides for these wants through the lacks it displays" (Knorr Cetina \& Bruegger, 2002b).

With regard to the theoretical link between individualization and consumption communities, we are now in a position to suggest that the retraction of social principles and structures is countered not only by the formation of neo-tribal consumer solidarities but also by 
consumer relationships with objects. According to this view, epistemic consumption objects can neither be reduced to the role of catalysts of social links, nor do they contribute to the thinning out and flattening of social forms by isolating individuals, as suggested by Cova's (1997) postmodern rebellion against objects. To the contrary, as we have shown, epistemic consumption objects in fact provide for a new form of postsocial relation between human and object that no longer fits traditional sociological categories of sociality but which may increasingly replace human relations (Knorr Cetina, 1997, 2001).

\section{CONCLUSION}

The consumption object figures prominently in cultural and social-psychological consumer research on product involvement, relationship, and community. While our theories have grown increasingly sophisticated and comprehensive, the consumption object itself has remained conspicuously absent from the theoretical development. In this paper, we aim at addressing this gap. We draw form our research with individual online investors' interaction with the stock market in order to develop a theory of the epistemic consumption object. We argue that the epistemic object is characterized by a lack of ontological stability. It can never be fully attained by the consumer because it is never quite itself and exists only as a sequence of absences. In the case of the "stock-market-on-the-screen", its ontological object-ivity is only an ephemeral moment of stability - like a freeze-frame camera shot of an action sequence - in a chain of changes (Knorr Cetina, 2001). Yet, as the stock market unfolds and evolves on the screen, it gestures at what it might become but not yet is; and it is ontologically ill-defined, question-generating property of the market, its uncertain future, that motivates the investor to continuously observe, interact with, and analyze it. In this context, we suggest that the epistemic consumption object has come to complement, if not substitute, exiting social relationships 
typically conceptualized as between humans to produce what we call postsocial forms of consumption.

Postsocial consumption is not necessarily a new phenomenon. We would suggest that the concept of the epistemic consumption object allows us to revisit and retheorize such consumption activities like skydiving, whitewater rafting, the construction of personal web pages, Star Trek, and baseball as postsocial object relations. The ontological incompleteness of 'nature', the 'Chicago Cubs', 'personal home pages', and 'Star Trek' provides for the 'sequence of absences' that at the same time addresses and constitutes the consumer as a 'structure of wanting', sustaining an ongoing engagement between the two. Put differently, the object, signaling what it might become (deadly? World Champion? playful? sequel?) and the self, trying to discern the still absent object, forge a structural link binding them together in what we call a postsocial consumption relationship (cf. 1997; Knorr Cetina, 2001). In this dialogical movement, the object extends the self, but not in Belk's sense (1988). Belk theorized the consumption object as an ontologically fixed entity appropriated as a constellation of signs by consumer selves negotiating their identities, which they mobilize to relate to other humans. Thus Belk's consumer self instrumentalizes possessions for the double purpose of achieving some degree of ontological security (see also Giddens, 1991) and for signaling a desired notion of self to other individuals. It is the instrumental value of the object for the purpose of identification, representation, communing, and experiencing that is at the center of Belk's concept of the materialistic self rather than the relationship between the self and the object. Within a postsocial consumer-object theory, the extension of the self is more accurately understood as an extension of relationships to the object world. In other words the unfolding object is not the means but the end of the extension. 
The epistemic consumption object encourages consumer researchers to reexamine established concepts such as relationship and involvement theory as well as theories of collective consumption. Brand relationships and product involvement have not previously been conceptualized with any systematic theory of the object. As we have shown in this paper, introducing such a theory opens up a new universe of concepts and tools for analysis and enriches our current state of knowledge of the origin and sustainability of product and brand relationships. Furthermore, it seems to us that the concept of the epistemic consumption object provides us with a promising theoretical access to phenomena such as obsessive computer and video gaming, the participation levels in fantasy sport leagues, the success of Internet blogs, and the craze caused by interactive toys like Furby and Poo-Chi. Certainly, technology and hightechnology products are obvious examples for epistemic consumption objects because of their frequent updating and structural complexity. Yet, the speed of scientific discovery combined with the ability to "virtualize" and network products (cf. Frels, Shervani, \& Srivastava, 2003) may even turn what arguably were hitherto perceived non-technological product categories such as food, clothing, and cosmetics into epistemic objects. Hence, we believe our research has the potential to inform and improve our understanding of strong consumer relations, attachment, and involvement with objects more generally.

Currently, consumer researchers define material possession attachment as the psychological and emotional appropriation of the object, which is singularized and decommodified in the process (Kleine \& Menzel Baker, 2004). In addition, attachment possessions have been defined as "extraordinary, mysterious, and emotion evoking rather than merely functional" (Belk, 1992a, p. 45). Similarly, Fournier (1998) returns to notions of self formation, identity construction, life project support, and meaning provision to conceptualize 
consumer-brand relationships. None of these characterizations are in dispute. They may, however, overlook part of the story. Given the results from our study, we suggest that such statements and definitions must be slightly revised and extended in at least two ways. First, for an object to become an object of attachment it neither needs to be emotion evoking nor psychologically nor emotionally appropriated, as understood in the attachment literature. Second, the object can be an object of attachment without having been singularized and decommodified by historical, cultural, or psychological forces and the object can be first and foremost functional, as long as it is epistemic. In short, our research suggests that concepts like attachment, involvement, and relationship, currently generally theorized as positive emotional ties, need to be retheorized to include a notion of lack (the object always already becoming something else) and a corresponding structure of wanting (the consumer always anticipating and discerning the next form) as origin and continuous fueling of attachment.

Finally, we challenge Cova's $(1997 ; 2001)$ postmodern conjecture of a collective rebellion against isolating objects. In his critique of consumer culture, Cova proposes that there could be a decrease in the consumption of products and services which isolate people and that the number of objects brining people together is decreasing. As a result, individuals are drawn to vectors of linking not sold in the market. We, on the other hand, argue that objects become increasingly important for consumers looking for new forms of sociality in the age of individualization and risk. In particular objects that have been criticized for their potentially isolating quality like computers, computer games, and the Internet may in fact provide for new forms of social link. Cova's postmodern leitmotif - the link is more important than the thing (e.g. the thing is only the societal support of the link) - misses the point. In a postsocial consumer culture, the thing is the link. 
Echoing Muniz and O’Guinn (2001, p. 415), we do not believe it furthers our understanding of consumer culture in the twenty-first century to theorize concepts of sociality and community in opposition to the progressive colonization of lifeworlds by rationalized commercial elements - even as we join Cova in decrying such trends. To be sure, commercial modernization penetrates and alters taken-for-granted lifeworlds, but it does not abolish the condition of possibility for sociality. In fact, the market increasingly provides the material for socialities with objects, and not just the material for traditional consumption communities described richly in the literature. We surmise that the "object-world" has always been intertwined with our lifeworlds (Douglas \& Isherwood, 1979; McCracken, 1987; Stearns, 2001), and contemporary expressions of object-centerdness, or what Knorr Cetina and Bruegger (2000) call the "object shift," denotes a new form of object orientation. To understand these shifts in consumer culture, the concept of the epistemic consumption object is a powerful addition to our analytical toolbox. 


\section{References}

Abolafia, M. Y. (1996). Making Markets: Opportunism and Restraint on Wall Street. Cambridge, MA: Harvard University Press.

Appadurai, A. (1993). Disjuncture and Difference in the Global Cultural Economy. In B. Robbins (Ed.), The Phantom Public Sphere (pp. 269-295). Minneapolis, MN: University of Minnesota Press.

Arnould, E. J., \& Price, L. L. (1993). River Magic: Extraordinary Experience and the Extended Service Encounter. Journal of Consumer Research, 20(June), 24-45.

Bagozzi, R. P., \& Dholakia, U. M. (2002). Intentional Social Action in Virtual Communities. Journal of Interactive Marketing, 16(2), 2-21.

Baudrillard, J. (1994). The System of Collecting. In J. Elsner \& R. Cardinal (Eds.), The Cultures of Collecting (pp. 7-24). Cambridge, MA: Harvard University Press.

Bauman, Z. (2003). Liquid love: On the frailty of human bonds. Cambridge, UK: Polity Press.

Beck, U. (1992). Risk society: Towards a new modernity. London: Sage Publications.

Beck, U., \& Beck-Gernsheim, E. (1996). Individualization and 'Precarious Freedoms':

Perspectives and Controversies of a Subject-Oriented Sociology. In P. Heelas, S. Lash \& P. Morris (Eds.), Detraditionalization (pp. 23-48). Oxford: Blackwell.

Beck, U., \& Beck-Gernsheim, E. (2002). Individualization: Institutionalized individualism and its social and political consequences. London and Thousand Oaks, Calif.: Sage.

Beck, U., Bonss, W., \& Lau, C. (2003). The Theory of Reflexive Modernization. Theory, Culture \& Society, 20(2), 1-33.

Belk, R., \& Costa, J. (1998). The Mountain Myth: A Contemporary Consuming Fantasy. Journal of Consumer Research, 25(December), 218-240.

Belk, R. W. (1988). Possessions and the Extended Self. Journal of Consumer Research, 15(September), 139-168.

Belk, R. W. (1992a). Attachment to Possessions. In S. M. Low \& I. Altman (Eds.), Place Attachment: Human Behavior and Environment (pp. 37-62). New York: Plenum Press.

Belk, R. W. (1992b). Moving possessions: An analysis based on personal documents from the 1847-1869 Mormon migration. Journal of Consumer Research, 19(December), 339-361.

Belk, R. W., Ger, G., \& Askegaard, S. (2003). The Fire of Desire: A Multisited Inquiry into Consumer Passion. Journal of Consumer Research, 30(3), 326-351.

Belk, R. W. \& Tumbat, G. (2005). The Cult of Macintosh. Consumption, Markets \& Culture, 8 (3, September), 205-217.

Belk, R. W., Wallendorf, M., \& Sherry, J. F. (1989). The Sacred and the Profane in Consumer Behavior: Theodicy on the Odyssey. Journal of Consumer Research, 16(1), 1-38.

Benjamin, W. (1968). Unpacking My Library - A Tall About Book Collecting. In H. Arendt (Ed.), Illuminations (pp. 59-67). New York: Schocken Books.

Bloch, P. H., \& Richins, M. L. (1983). A Theoretical Model for the Study of Product Importance Perceptions. Journal of Marketing, 47(Summer), 69-81.

Bonsu, S. K., \& Belk, R. (2003). Do not go cheaply into that good night: Death-ritual consumption in Asante, Ghana. Journal of Consumer Research, 30(1), 41-55.

Bouchet, D. (1998). Information technology, the social bond and the city -- Georg Simmel revisited, Built Environment, 24(2/3), 104-133.

Bourdieu, P. (1984). Distinction - A Social Critique of the Judgment of Taste. Cambridge, MA: Harvard University Press. 
Burns, R. (1995). German Cultural Studies. Oxford, England: Oxford University Press.

Castells, M. (1996). The Rise of the Network Society. Malden, MA: Blackwell.

Castells, M. (2001). The Internet Galaxy: Reflections on the Internet, business, and society. Oxford and New York: Oxford University Press.

Celsi, R. L., \& Olson, a. J. C. (1988). The Role of Involvement in Attention and Comprehension Processes. Journal of Consumer Research, 15(2), 210-224.

Celsi, R. L., Rose, R. L., \& Leigh, T. W. (1993). An Exploration of High-Risk Leisure Consumption Through Skydiving. Journal of Consumer Research, 20(June), 1-23.

Cohen, A. P. (1985). The symbolic construction of community. London: Tavistock Publ.

Comaroff, J. (1996). The Empire's Old Clothes: Fashioning the Colonial Subject. In D. Howes (Ed.), Cross-cultural consumption (pp. 19-38). London and New York: Routledge.

Coulter, R. A., Price, L. L., \& Feick, L. (2003). The Origins of Involvement and Brand Commitment: Insights from Postsocialist Central Europe. Journal of Consumer Research, 30(September), 170-183.

Cova, B. (1997). Community and consumption: Towards a definition of the linking value of product or services. European Journal of Marketing, 31(3/4), 297-316.

Cova, B., \& Cova, V. (2001). Tribal aspects of postmodern consumption research: The case of French in-line roller skaters. Journal of Consumer Behaviour, 1(1), 67-76.

Davis, F. D., Bagozzi, R. P., \& Warshaw, P. R. (1992). Extrinsic and Intrinsic Motivations to use Computers in the Workplace. Journal of Applied Social Psychology, 22(14), 1111-1132.

Douglas, M., \& Isherwood, B. (1979). The World of Goods. New York: Basic Books.

Drucker, P. F. (1993). Post-Capitalist Society. New York: HarperBusiness.

Firat, A. F., \& Dholakia, N. (1997). Consuming People: From Political Economy to Theaters of Consumption. London \& New York: Routledge.

Firat, A. F., \& Venkatesh, A. (1995). Liberatory Postmodernism and the Reenchantement of Consumption. Journal of Consumer Research, 22(3), 239-267.

Fournier, S. (1998). Consumers and their brands: Developing relationship theory in consumer research. Journal of Consumer Research, 24(4), 343-373.

Frels, J. K., Shervani, T., \& Srivastava, R. K. (2003). The Integrated Networks Model: Explaining Resource Allocations in Network Markets. Journal of Marketing, 67(1).

Giddens, A. (1991). Modernity And Self-Identity: Self And Society In The Late Modern Age. Stanford, CA: Stanford University Press.

Giddens, A. (1994). Living in a Post-Traditional Society. In U. Beck, A. Giddens \& S. Lash (Eds.), Reflexive Modernization (pp. 56-109). Stanford: Stanford University Press.

Giulianotti, R. (1996). Back to the future: An ethnography of Ireland's football fans at the 1994 World Cup Finals in the USA. International Review for Sociology of Sport, 31(2), 323342.

Habermas, J. (1981). Theorie des kommunikative Handelns, Band 1. Frankfurt am Main: Suhrkamp.

Habermas, J. (1994). Individualisierung und Vergesellschaftung. In U. Beck \& E. BeckGernsheim (Eds.), Riskante Freiheiten: Individualisierung in modernen Gesellschaften (pp. 437-446). Frankfurt: Suhrkamp.

Heelas, P., Lash, S., \& Morris, P. (1996). Detraditionalization: Critical reflections on authority and identity. Cambridge, Mass.: Blackwell Publishers.

Hirschman, E. C. (1994). Consumers and their animal companions. Journal of Consumer Research, 20(March), 616-632. 
Hoffman, D. L., \& Novak, T. P. (1996). Marketing in Hypermedia Computer-Mediated Environments: Conceptual Foundations. Journal of Marketing, 80(1), 50-68.

Holbrook, M. B., Stephens, D. L., Day, E., Holbrook, S. M., \& Strazar, G. (2001). A Collective Stereographic Photo Essay on Key Aspects of Animal Companionship: The Truth About Dogs and Cats. Academy of Marketing Science Review, 1, 1-17.

Holt, D. B. (1995). How Consumer Consume: A Typology of Consumption Practices. Journal of Consumer Research, 22(June), 1-16.

Holt, D. B. (1998). Does Cultural Capital Structure American Consumption? Journal of Consumer Research, 25(June), 1-25.

Kleine, R. E., III, \& Kernan, J. B. (1991). Contextual Influences on the Meanings Ascribed to Ordinary Consumption Objects. Journal of Consumer Research, 18(3), 311-324.

Kleine, S., Kleine, R. E. I., \& Allen, C. T. (1995). How is a possession "me" or "not me"? Characterizing types and an antecedent of material possession attachment. Journal of Consumer Research, 22(3), 327-344.

Kleine, S. S., \& Menzel Baker, S. (2004). An Integrative Review of Material Possession Attachment. Academy of Marketing Science Review, 1, 1-39.

Knorr Cetina, K. D. (1997). Sociality with Objects. Social Relations in Postsocial Knowledge Societies. Theory, Culture and Society, 14(4), 1-30.

Knorr Cetina, K. D. (1999). Epistemic cultures: How the sciences make knowledge. Cambridge, Mass. and London: Harvard University Press.

Knorr Cetina, K. D. (2001). Postsocial Relations: Theorizing Sociality in a Post-social Environment. In G. Ritzer \& B. Smart (Eds.), Handbook of social theory (pp. 520-537). London and Thousands Oaks, Calif.: Sage.

Knorr Cetina, K. D., \& Bruegger, U. (2000). The Market as an Object of Attachment: Exploring Postsocial Relations in Financial Markets. Canadian Journal of Sociology, 25(2), 141 168.

Knorr Cetina, K. D., \& Bruegger, U. (2002a). Global Microstructures: The Virtual Societies of Financial Markets. American Journal of Sociology, 107(4), 905-950.

Knorr Cetina, K. D., \& Bruegger, U. (2002b). Traders' Engagement with Markets. Theory, Culture, and Society, 19(5/6), 161-185.

Kozinets, R. V. (1999). E-Tribalized Marketing?: The Strategic Implications of Virtual Communities of Consumption. European Management Journal, 17(3), 252-264.

Kozinets, R. V. (2001). Utopian enterprise: Articulating the meanings of Star Trek's culture of consumption. Journal of Consumer Research, 28(1), 67-88.

Kozinets, R. V. (2002a). Can Consumers Escape the Market? Emancipatory Illuminations from Burning Man. Journal of Consumer Research, 29(1), 20-38.

Kozinets, R. V. (2002b). The Field Behind the Screen: Using Netnography for Marketing Research in Online Communities. Journal of Marketing Research, 39(February), 61-72.

Latour, B. (1987). Science in action: How to follow scientists and engineers through society. Cambridge, Mass.: Harvard University Press.

Latour, B. (1993). We have never been modern. Cambridge, Mass.: Harvard University Press.

Latour, B. (1996). Aramis, or, The love of technology. Cambridge, Mass.: Harvard University Press.

Latour, B., \& Woolgar, S. (1979). Laboratory life: The social construction of scientific facts. Beverly Hills: Sage Publications. 
Lyng, S. G. (1990). Edgework: A Social Psychological Analysis of Voluntary Risk Taking. American Journal of Sociology, 95(January), 851-886.

Maffesoli, M. (1996). The Times of the Tribes (D. Smith, Trans.). London: Sage.

Marcoux, J.-S. (2001). The 'Casser Maison' Ritual: Constructing the Self by Emptying the Home. Journal of Material Culture, 6, 213-235.

McAlexander, J. H., Schouten, J. W., \& Koening, H. F. (2002). Building brand community. Journal of Marketing, 66(1), 38-54.

McCracken, G. (1987). The history of consumption: A literature review and consumer guide. Journal of Consumer Policy, 10, 139-166.

Mehta, R., \& Belk, R. W. (1991). Artifacts, Identity, and Transition: Favorite Possessions of Indians and Indian Immigrants to the United States. Journal of Consumer Research, 17(4), 398-411.

Miller, D. (1998). Material cultures: Why some things matter. Chicago: University of Chicago Press.

Miller, D. (2001). Home possessions: Material culture behind closed doors. Oxford: Berg.

Moon, Y. (2004). Don't Just Do Something, Stand There! Harvard Business Review, 82(3), 1617.

Muniz, A. M., \& O'Guinn, T. C. (2001). Brand Community. Journal of Consumer Research, 27(4), 412-432.

Penaloza, L. (1994). Crossing boundaries/drawing lines: A look at the nature of gender boundaries and their impact on marketing research. International Journal of Research in Marketing, 11, 359-379.

Penaloza, L. (2001). Consuming the American West: Animating cultural meaning and memory at a stock show and rodeo. Journal of Consumer Research, 28(3), 369-398.

Rheinberger, H.-J. (1992). Experiment, difference, and writing: I. Tracing protein synthesis. Studies in the History and Philosophy of Science, 23(2), 305-331.

Rheinberger, H.-J. (1997). Toward a history of epistemic things: Synthesizing proteins in the test tube. Stanford, Calif.: Stanford University Press.

Rook, D. W. (1985). The Ritual Dimension of Consumer Behavior. Journal of Consumer Research, 12(December), 251-264.

Schau, H. J., \& Gilly, M. C. (2003). We Are What We Post? The Presentation of Self in Personal Webspace. Journal of Consumer Research, 30(3), 385-404.

Schouten, J. W., \& McAlexander, J. H. (1995). Subcultures of Consumption: An Ethnography of the New Bikers. Journal of Consumer Research, 22, 43-61.

Schroeder, J., \& Zwick, D. (2004). Mirrors of Masculinity: Representation and Ontology in Advertising Images. Culture, Markets, and Consumption, 7(1), 21-51.

Sennett, R. (1998). The corrosion of character: The personal consequences of work in the new capitalism (1st ed.). New York: Norton.

Serres, M., \& Latour, B. (1995). Conversations on science, culture, and time. Ann Arbor: University of Michigan Press.

Shapiro, C., \& Varian, H. R. (1999). Information Rules: A Strategic Guide to the Network Economy. Boston, Mass.: Harvard Business School Press.

Sherry, J. F. (1990). A Sociocultural Analysis of a Midwestern American Flea Market. Journal of Consumer Research, 17(June), 13-30.

Smith, C. W. (1981). The Mind of the Market. London: Croom Helm. 
Sparke, P. (1995). As long as it's pink: The sexual politics of taste. London; San Francisco, Calif: Pandora.

St. John, G. (2004). Rave culture and religion. London and New York: Routledge.

Staute, J. (1998). Borsenfieber: Was Anleger im Aktienrausch wissen sollten. Frankfurt a. M. and New York: Campus.

Stearns, P. N. (2001). Consumerism in world history: The global transformation of desire. London and New York: Routledge.

Stehr, N. (1994). Knowledge societies. London Thousand Oaks, Calif.: Sage.

Stehr, N. (2001a). The fragility of modern societies: Knowledge and risk in the information age. London and Thousand Oaks, Calif.: Sage.

Stehr, N. (2001b). Modern societies as knowledge societies. In G. Ritzer \& B. Smart (Eds.), Handbook of social theory (pp. 494-508). London and Thousands Oaks, Calif.: Sage.

Swedberg, R. (1994). Markets and Social Structures. In N. J. Smelser \& R. Swedberg (Eds.), The Handbook of Economic Sociology (pp. 255-282). Princeton, NJ: Princeton University Press.

Thompson, C. J., Locander, W. B., \& Pollio, H. R. (1989). Putting Consumer Experience Back Into Consumer Research: The Philosophy and Method of Existential-Phenomenology. Journal of Consumer Research, 16(2), 133.

Thompson, C. J., \& Tambyah, S. K. (1999). Trying to be Cosmopolitan. Journal of Consumer Research, 26(3), 214-241.

Tönnies, F. (1979). Gemeinschaft und Gesellschaft: Grundbegriffe der reinen Soziologie (8. Aufl. ed.). Darmstadt: Wissenschaftliche Buchgesellschaft.

Turkle, S. (1995). Life on the Screen. New York, NY: Touchstone.

Turkle, S. (2003). Technology and Human Vulnerability. Harvard Business Review, 81(9), 4350 .

Wallendorf, M., \& Arnould, E. J. (1988). My Favorite Things: A Cross-Cultural Inquiry Into Object Attachement, Possesiveness, and Social Likage. Journal of Consumer Research, 14(March), 531-547.

Wallulis, J. (1998). The New Insecurity. Albany: SUNY Press.

Weber, M. (1958). The Protestant Work Ethic and the Spirit of Capitalism. New York: Charles Scribner's Sons.

Zaichkowsky, J. L. (1985). Measuring the Involvement Construct. Journal of Consumer Research, 12(December), 341-352.

Zaichkowsky, J. L. (1986). Conceptualizing Involvement. Journal of Advertising, 15(2), 4-14.

Zwick, D., \& Dholakia, N. (2006). Bringing the market to life: screen aesthetics and the epistemic consumption object. Marketing Theory. (forthcoming) 
Table 1: Profile of Participants

\begin{tabular}{|c|c|c|c|c|c|}
\hline Pseudonym & Age & Family Status & $\begin{array}{l}\text { Profession/Edu } \\
\text { cation }\end{array}$ & Nationality & $\begin{array}{l}\text { Household } \\
\text { Income/\$Year }\end{array}$ \\
\hline Herbert & 37 & Married & Manager/MBA & German & 50,000 \\
\hline Joachim & 36 & Single & Teacher/PhD & German & 25,000 \\
\hline Manfred & 37 & Single & $\begin{array}{l}\text { information } \\
\text { technology } \\
\text { Developer/M.S }\end{array}$ & German & 60,000 \\
\hline Markus & 30 & Single & $\begin{array}{l}\text { Project } \\
\text { Manager/M.S. }\end{array}$ & German & 50,000 \\
\hline Theo & 44 & Divorced & Lawyer/JD & German & 70,000 \\
\hline Michael & 25 & Single & Student & German & 30,000 \\
\hline Eberhard & 37 & Married & $\begin{array}{l}\text { Journalism/M. } \\
\text { A. }\end{array}$ & German & 40,000 \\
\hline Sebastian & 37 & Married & Engineer/M.S. & German & n.a. \\
\hline Steffen & 36 & Married & Banker/MBA & German & 40,000 \\
\hline Oliver & 31 & Single & Teacher/ M.S. & German & 14,000 \\
\hline Harald & 28 & Married & Teacher/ M.A. & German & 24,000 \\
\hline Christian & 25 & Single & Student & German & 7,000 \\
\hline Peter & 36 & Single & Academia/PhD & German & 65,000 \\
\hline Klaus & 35 & Married & $\begin{array}{l}\text { System } \\
\text { Administrator/ } \\
\text { M.S. }\end{array}$ & German & 60,000 \\
\hline Rudolf & 36 & Married & $\begin{array}{l}\text { Biotechnologis } \\
\text { t M.S. }\end{array}$ & German & 40,000 \\
\hline Larry & 20 & Single & Soldier/ B.A. & American & 25,000 \\
\hline Richard & 21 & Singe & Student & American & n.a. \\
\hline Susan & 21 & Single & Student & American & 10,000 \\
\hline Claudia & 28 & Single & $\begin{array}{l}\text { Account } \\
\text { Executive/MB } \\
\text { A }\end{array}$ & American & 50,000 \\
\hline Kenny & & & Academia/PhD & American & n.a. \\
\hline
\end{tabular}




\begin{tabular}{|l|l|l|l|l|l|}
\hline Peter & 25 & Single & $\begin{array}{l}\text { Sales } \\
\text { Rep./B.A. }\end{array}$ & American & 40,000 \\
\hline Ernie & 32 & Single & Manager/MBA & American & 60,000 \\
\hline Eric & 43 & Married & $\begin{array}{l}\text { Ad Designer/ } \\
\text { M.A. }\end{array}$ & American & 80,000 \\
\hline John & 34 & Married & Academia/PhD & American & 50,000 \\
\hline Jacqueline & 48 & Married & $\begin{array}{l}\text { Manager/ } \\
\text { M.B.A. }\end{array}$ & American & n.a. \\
\hline Keith & 22 & Single & Student & American & 10,000 \\
\hline
\end{tabular}

1 We acknowledge that the use of the term object to designate animals is hazardous. However, we have defined objects here very broadly as non-human entities, which include animals. At any rate, we fully agree with Holbrook et al's critique of Belk who included animals in his "extension of self" view of objects. In fact, we will argue below that even non-animal objects, what we call epistemic consumption objects, cannot be reduced to Belk's position on self-extension.

2 By unstructured we mean that there was no predetermined regularity or length of any one correspondence. Typically, after a sharp rise or fall of the market or movements and announcements concerning particular prominent stocks, one of the researchers would seize the opportunity and contact these informants to obtain feedback on their thoughts on the specific event, other recent occurrences, and more general thoughts on investing. 